\title{
Development of alternative fuel electrodes for upgrading biogas through $\mathrm{CO}_{2}$
}

\author{
Nuoxi Zhang ${ }^{\mathrm{a}}$, Yunfeng Tian ${ }^{\mathrm{a}, \mathrm{b}}$, Xiangling Yue ${ }^{\mathrm{a}}$, Lauren Sammes ${ }^{\mathrm{a}, \mathrm{c}}$, and John Irvine ${ }^{\mathrm{a}}$

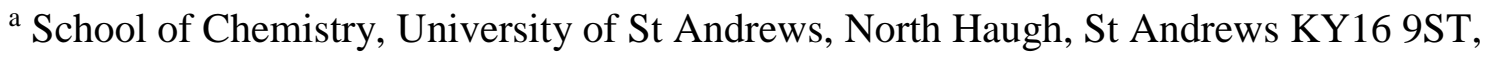 \\ UK \\ ${ }^{\mathrm{b}}$ School of Material Science and Engineering, Huazhong University of Science \& \\ Technology, Wuhan 430074, China \\ ${ }^{\mathrm{c}}$ Low Emission Resources Corp, 17 State Street, Suite 1900, New York, NY 10004, US
}

Due to the large amount of carbon dioxide in biogas reducing its flame velocity, flammability range, heating value as well as power output, the biogas must be upgraded to a higher value product. In this paper, direct feeding of simulated biogas to SOECs has been investigated; in particular, two different fuel electrode materials which are nickel with $8 \%$ yttrium-stabilized zirconia (Ni-YSZ) and $\mathrm{La}_{0.43} \mathrm{Ca}_{0.37} \mathrm{Ni}_{0.05} \mathrm{Ti}_{0.95} \mathrm{O}_{3-}$ (LCNT) incorporated with $8 \mathrm{~mol} \%$ yttrium-stabilized zirconia (8YSZ) electrolyte and $\mathrm{La}_{1-}{ }_{\mathrm{x}} \mathrm{Sr}_{\mathrm{x}} \mathrm{MnO}_{3}$ perovskite (LSM)-yttria-stabilized zirconia (YSZ) composite air electrode have been tested. Both cells demonstrate feasible way for biogas electrolysis.

\section{Introduction}

Biogas is a type of biofuel, which consists of roughly $60 \%$ methane, $40 \%$ carbon dioxide as well as other small amounts of 'contaminant' gases, for example, hydrogen sulphide, siloxanes and water (1). However, because of the large amount of carbon dioxide in biogas, the energy density of the volume of biogas is extremely low. Therefore, the biogas must be upgraded to a higher value product.

Dry reforming of biogas has received the most attention. The main products of biogas dry reforming are carbon monoxide and hydrogen (2), as shown in eqn (1).

$$
\mathrm{CH}_{4}+\mathrm{CO}_{2} \rightarrow 2 \mathrm{CO}+2 \mathrm{H}_{2}\left(\Delta \mathrm{H}^{0}{ }_{298 \mathrm{k}}=247 \mathrm{~kJ} / \mathrm{mol}\right)
$$

Dry reforming of biogas not only reduces the major greenhouse gases, carbon dioxide and methane, but also generates a more valuable product, syngas, which is the building block for the production of gasoline or diesel via Fischer-Tropsch synthesis and oxygenated chemicals (3). The dry reforming reaction of biogas is extremely endothermic, therefore, this reaction is usually performed at high temperature, in the range of 650$1000{ }^{\circ} \mathrm{C}$, to achieve high $\mathrm{CO}_{2}$ and $\mathrm{CH}_{4}$ conversion (4). The operating temperature range of the SOEC is between 700 and $1000{ }^{\circ} \mathrm{C}$, which is matched with that of dry biogas reforming reaction. The high requirement of thermal energy in SOECs can be obtained from a nuclear reactor or geothermal sources, etc. Moreover, surplus electricity from renewable energy sources (e.g. solar, wind, etc) can be used in SOECs to generate syngas and in the meantime, the demand for energy storage systems (e.g. pumped hydro storage, batteries, etc) that have 
ability to capture excess electricity in off-peak periods and return electricity back in highpeak periods is reduced (5).

Converting biogas, into a hydrocarbon fuel via syngas provides a potential technologically feasible and economically viable way of delivering renewable energy to customers. These advantages of upgrading biogas by SOECs have motivated research to further investigate the biogas electrolysis mechanism and new material development.

\section{Experimental}

Single cell fabrication. Two single cells were fabricated consisting of different fuel electrode material (LCNT and Ni-YSZ), $2 \mathrm{~mm}$ thick YSZ electrolyte and LSM-YSZ air electrode.

The perovskite $\mathrm{La}_{0.43} \mathrm{Ca}_{0.37} \mathrm{Ni}_{0.05} \mathrm{Ti}_{0.95} \mathrm{O}_{3-r}(\mathrm{LCNT})$ was prepared by a solid state route. High purity precursors including oxides $\left(\mathrm{TiO}_{2}\right.$ and $\left.\mathrm{La}_{2} \mathrm{O}_{3}\right)$, nitrates $\left(\mathrm{Ni}\left(\mathrm{NO}_{3}\right)_{2} * 6 \mathrm{H}_{2} \mathrm{O}\right)$ and carbonates $\left(\mathrm{CaCO}_{3}\right)$ were dried at different temperatures $\left(300-800{ }^{\circ} \mathrm{C}\right)$ and then weighted in the stoichiometric ratios. All the weighted precursors and appropriate amount of acetone were transferred into a beaker followed by adding non-aqueous KD-1 dispersant $(\sim 0.05$ wt.\%). In order to break agglomerates, the mixture was then gone through ultrasonic probe mixing. The acetone was then evaporated at $50{ }^{\circ} \mathrm{C}$ on the hot plate. After acetone was completely evaporated, the powder was then transferred into a crucible and calcined at $1200{ }^{\circ} \mathrm{C}$. The calcined powder was then ball milled and pressed into dense pellets. The resulting pellets were fired at $1400{ }^{\circ} \mathrm{C}$ for $12 \mathrm{~h}$. The sinter pellets were then crushed and ball milled at high speed to produce desired particle size powder for making ink. On the other hand, the powders of NiO, YSZ and LSM were provided by commercial company.

The ceramic powders of electrode material were weighed out, followed by KD-1 dispersant. The mixed powders were placed into a plastic bottle with zirconia milling balls. Then, acetone was poured into the plastic bottle. The mixture in the bottle was put on a roller ball mill for 24 hours in order to grind chemicals to a finer consistency. After roller ball milling, the mixture was poured into a beaker. This was followed by the addition of organic vehicles The resulting slurry in the beaker was covered by parafilm and then stirred on an electromagnetic plate using a magnetic stirrer until all the acetone had been evaporated from the slurry. Then the remaining slurry had formed the ink and was ready for use in screen-printing.

The electrode with higher sintering temperature was screen-printed and sintered first. Therefore, the fuel electrode $\mathrm{NiO}-\mathrm{YSZ}$ was fabricated first and fired at $1300{ }^{\circ} \mathrm{C}$ for 2 hours, while the air electrode LSM-YSZ was then sintered at $1100{ }^{\circ} \mathrm{C}$ with the same dwelling time. For LCNT/YSZ/LSM-YSZ cell, LCNT was screen-printed first and calcined at $1200{ }^{\circ} \mathrm{C}$ for 2 hours, followed by printing and sintering LSM-YSZ electrode.

$\mathrm{Pt}$ paste used as current collector for NiO-YSZ while Au pate used as current collector for LSM-YSZ and LCNT electrode.

Electrochemical characterization. The cells were mounted in a SOC testing jig (Fig.1) incorporate with gas supply system. In this experiment, different composition of simulated biogas was fed to the fuel electrode side, while air electrode side was exposed to the 
stationary air atmosphere. The electrodes were connected to VersaSTAT 3 for currentvoltage $(I-V)$, impedance and stability test measurement in a two-electrode system.

For Ni-YSZ/YSZ/LSM-YSZ cell, after NiO-YSZ composite electrode completely reduced to Ni-YSZ, sweep voltammetry was conducted from OCV to $-1.6 \mathrm{~V}$, followed by a short term stability test. In the meantime, the outlet gas from fuel electrode was analyzed using gas chromatography.

For LCNT/YSZ/LSM-YSZ cell, electrochemical switching was triggered first by applying a $2.3 \mathrm{~V}$ potential. After switching, I-V curve was measured from OCV to approximately $2 \mathrm{~V}$. Electrochemical Impedance Spectroscopy (EIS) were recorded in the range of $100 \mathrm{kHz}$ to $0.1 \mathrm{~Hz}$ under $20 \mathrm{mV}$ AC perturbation amplitude at OCV, $1.2 \mathrm{~V}, 1.4$ $\mathrm{V}, 1.6 \mathrm{~V}$ and $1.8 \mathrm{~V}$.

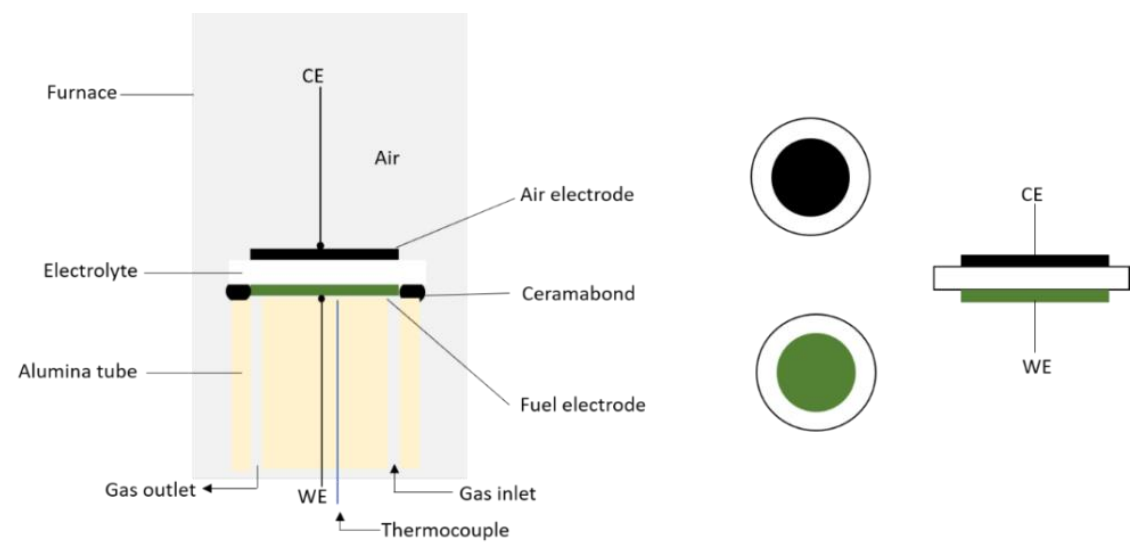

Figure 1. Schematic of cell testing set-up for electrochemical measurement

\section{Results and discussions}

Ni-YSZ/YSZ/LSM-YSZ. Electrolysis testing was performed for cell-1 at temperatures of $900{ }^{\circ} \mathrm{C}, 800{ }^{\circ} \mathrm{C}$ and $700^{\circ} \mathrm{C}$ with a gas mixture of $20 \% \mathrm{CO}_{2} / 20 \% \mathrm{CH}_{4} / 60 \%$ Ar. The electrolysis cell was tested at $900{ }^{\circ} \mathrm{C}$ first, followed by $800{ }^{\circ} \mathrm{C}$ and $700{ }^{\circ} \mathrm{C}$. The polarization curves (I-V curves) were recorded under applied voltage from OCV to approximately 1.6 $\mathrm{V}$ (Fig.2). The slope of polarization curve is represented by the area specific resistance (ASR). The ASR values for each polarization curve are summarized in Table 1. 


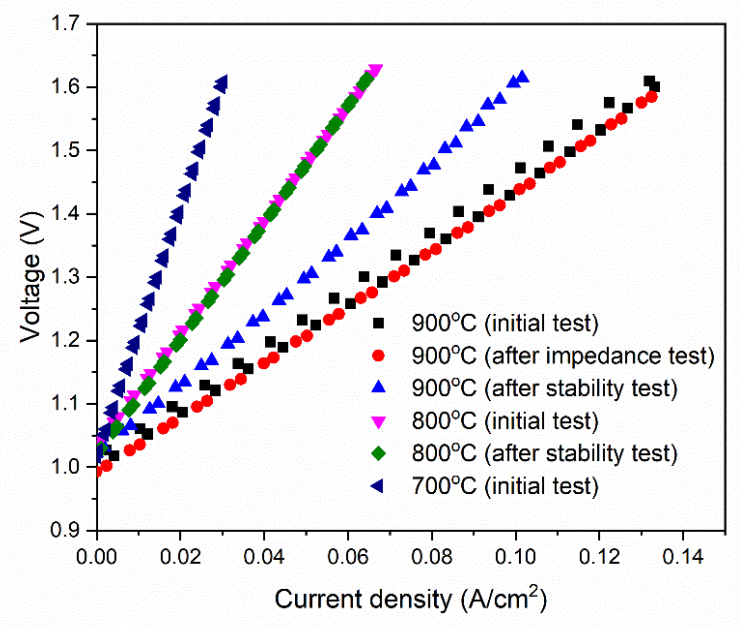

Figure 2. The I-V curves for cell-1 in $20 \% \mathrm{CO}_{2} / 20 \% \mathrm{CH}_{4} / 60 \%$ Ar mixture at different temperatures and conditions

TABLE I. The values of ASR at different operating conditions.

\begin{tabular}{ccc}
\hline & Time (h) & ASR $\left(\boldsymbol{\Omega} \mathbf{~ c m}^{2}\right)$ \\
\hline $900{ }^{\circ} \mathrm{C}$ (initial test) & 0 & 4.5 \\
$900{ }^{\circ} \mathrm{C}$ (after impedance test) & 2 & 4.5 \\
$900{ }^{\circ} \mathrm{C}$ (after stability test) & 25 & 5.8 \\
$800^{\circ} \mathrm{C}$ (initial test) & 30 & 8.9 \\
$800{ }^{\circ} \mathrm{C}$ (after stability test) & 48 & 9.2 \\
$700^{\circ} \mathrm{C}$ (initial test) & 50 & 19.6 \\
\hline
\end{tabular}

The calculated ASR for $900{ }^{\circ} \mathrm{C}$ (initial test) and $900{ }^{\circ} \mathrm{C}$ (after impedance test) are same. However, a lower ASR was observed after the overnight stability test. This indicates degradation of cell-1. The ASR increases rapidly from $900{ }^{\circ} \mathrm{C}$ to $800^{\circ} \mathrm{C}$ and from $800{ }^{\circ} \mathrm{C}$ to $700{ }^{\circ} \mathrm{C}$ due to the increase in ohmic resistance due to the decreasing ionic conductivity of electrolyte. The decreasing current density at constant voltage $1.6 \mathrm{~V}$ during the stability test of cell-1 (Fig. 3(a)) also supports the degradation of cell-1. The sharp decline in current density during the stability test at $700{ }^{\circ} \mathrm{C}$ (Fig. 3(b)) is mainly caused by losing contact between the wire and current collector. 


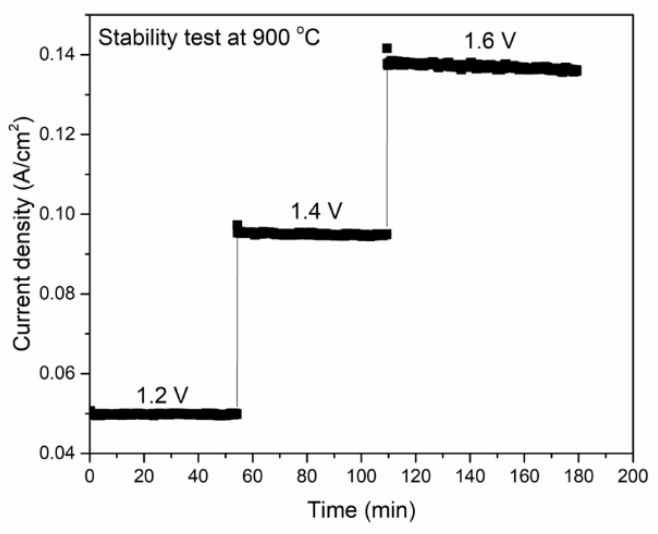

(a)

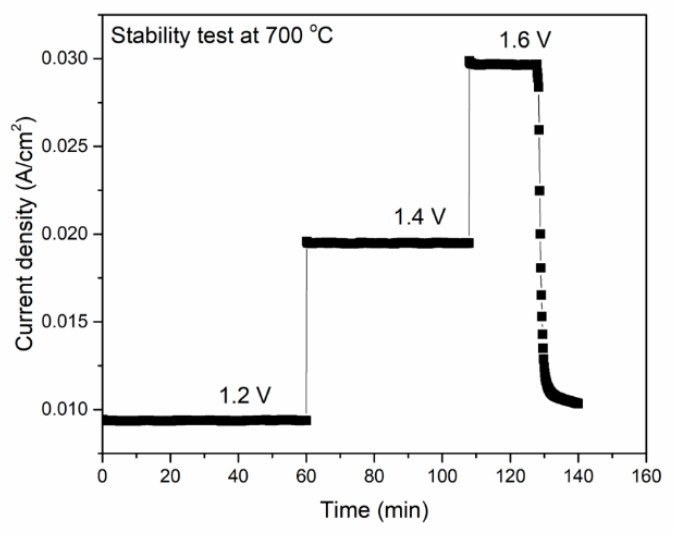

(b)

Figure 3. The stability test measured for cell-1 during electrolysis at constant voltage at (a) $900{ }^{\circ} \mathrm{C}$ and (b) $700{ }^{\circ} \mathrm{C}$

The degradation of the cell can be caused by carbon deposition on the active sites. The side reaction of methane decomposition proceeds endothermically at above $546.85{ }^{\circ} \mathrm{C}$ leading formation of graphite (6). However, the Boudouard reaction is exothermic. When the temperature increases to approximately $726.85{ }^{\circ} \mathrm{C}$, the reverse-Boudouard reaction occurs. Therefore, the graphite can then be eliminated by reacting with carbon dioxide to form carbon monoxide. The reaction rate of methane decomposition and reverseBoudouard reaction is unknown in this system. Hence, there may still be carbon deposition within the porous electrode. In order to check whether there is any coking in the cell, the cross-section of cell-1 was observed by using scanning electron microscope and the resulting image(s) are shown in Fig. 4. The carbon nanofibers were not found even under x5000 magnification within the Ni/YSZ electrode (Fig. 4 (b2)). This means that coking is not the reason for the degradation in cell performance.

Material instability at high temperature can also cause lower performance in solid oxide electrolysis cells. There are three possible causes of material instability: (1)Pyrochlore compounds could be formed at the air electrode (LSM)/electrolyte interface (7). They possess low conductivity and increase the cell resistance, leading to relatively poor cell performance. (2) The ionic conductivity of electrolyte $\left(8 \mathrm{~mol} \% \mathrm{Y}_{2} \mathrm{O}_{3}\right.$-stabilized zirconia) decreases with increasing operation time due to phase instability (7). (3) Ni particles in the fuel electrode tend to agglomerate at high temperature in long-term testing (8). The agglomeration of $\mathrm{Ni}$ reduces the triple-phase boundaries (TPB) and thereby increases overpotentials. 

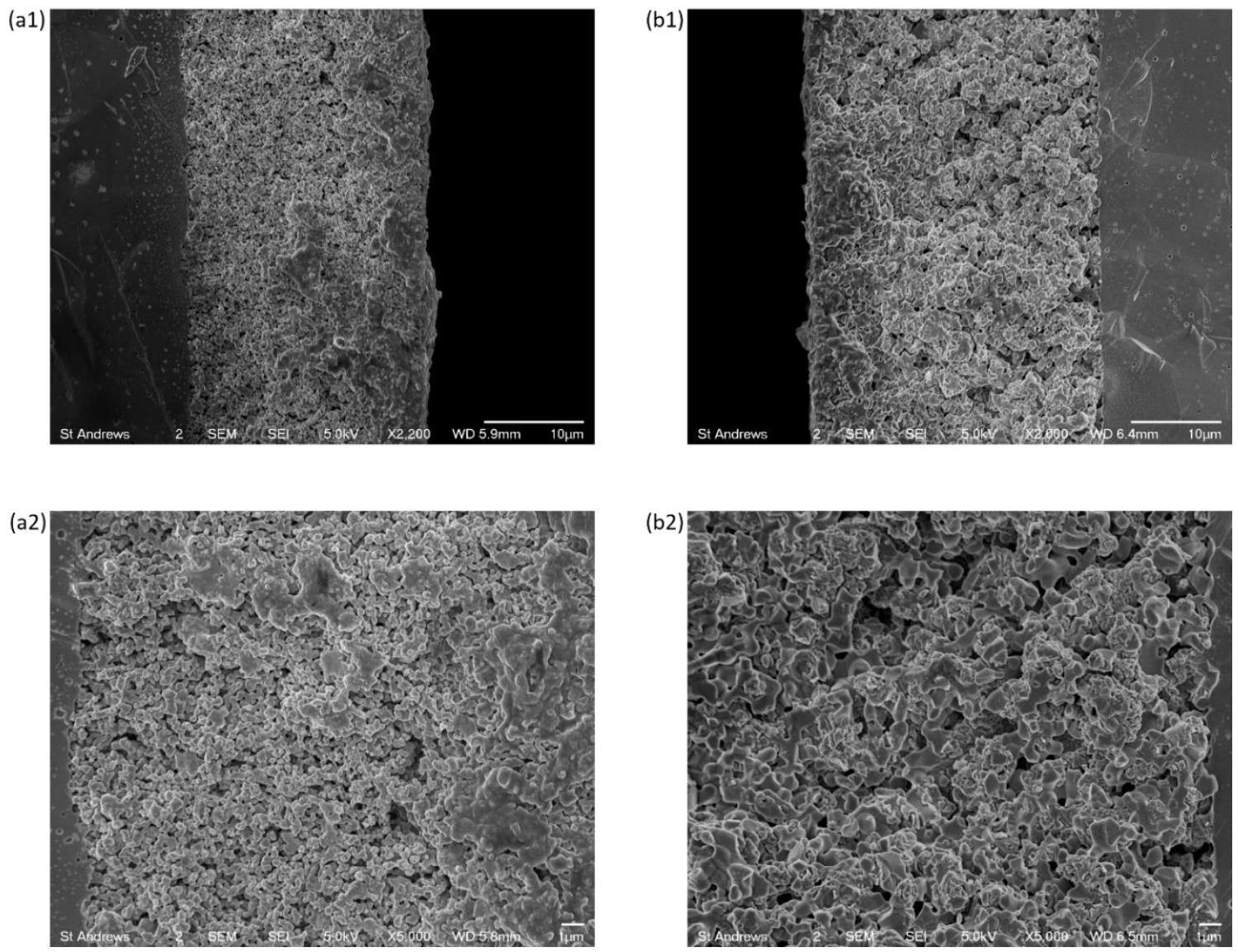

Figure 4. SEM images on the left-hand side is (a1) (a2) LSM-YSZ electrode; and on the right-hand side is (b1) (b2)Ni-YSZ electrode

The outlet gas from fuel electrode was analysed using gas chromatography during the short-term stability test. As shown in Fig. 5 (a1) and (a2), the conversion of $\mathrm{CO}_{2}$ and $\mathrm{CH}_{4}$ at $900{ }^{\circ} \mathrm{C}$ and $1.2 \mathrm{~V}$ is $83 \%$ and $76 \%$, while the conversion of $\mathrm{CO}_{2}$ and $\mathrm{CH}_{4}$ at $700{ }^{\circ} \mathrm{C}$ under $1.2 \mathrm{~V}$ is $46 \%$ and $50 \%$. The conversion for both gases at $700{ }^{\circ} \mathrm{C}$ is much lower compared to the conversion of $\mathrm{CO}_{2}$ and $\mathrm{CH}_{4}$ at $900{ }^{\circ} \mathrm{C}$. This is mainly due to the higher reaction rates at higher temperature. In addition, $\mathrm{CO}_{2}$ conversion is higher than the $\mathrm{CH}_{4}$ conversion at $900{ }^{\circ} \mathrm{C}$, whereas it is in the opposite way at $700{ }^{\circ} \mathrm{C}$ suggesting the influence of the reverse water gas shift reaction. The reverse water gas shift reaction only occurs when the operation temperature equals or above $900{ }^{\circ} \mathrm{C}$. Otherwise, the water gas shift reaction proceeds instead. 

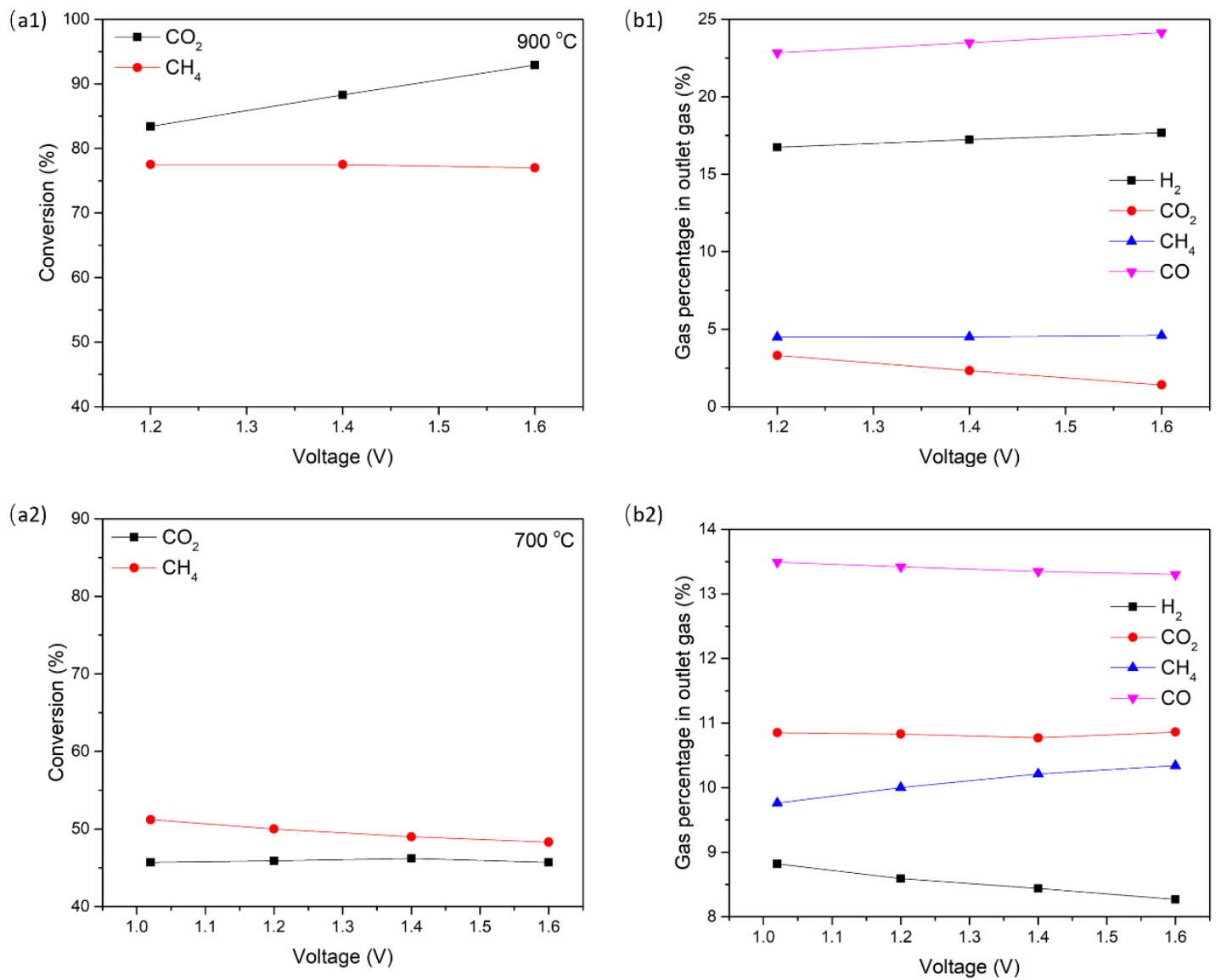

Figure 5. The conversion of $\mathrm{CO}_{2}$ and $\mathrm{CH}_{4}$ at (a1) $900{ }^{\circ} \mathrm{C}$ and (a2) $700{ }^{\circ} \mathrm{C}$; The percentage of unreacted gas and product in the outlet gas at (b1) $900{ }^{\circ} \mathrm{C}$ and (b2) $700{ }^{\circ} \mathrm{C}$

The $\mathrm{CO}_{2}$ conversion increases along with the applied voltages at $900{ }^{\circ} \mathrm{C}$, indicating that the high voltage remarkably promotes the electrochemical process. But the $\mathrm{CH}_{4}$ conversion is independent of applied voltages, illustrating that all oxide ions pass through the electrolyte to the air electrode. At $700{ }^{\circ} \mathrm{C}$, the conversion of $\mathrm{CO}_{2}$ and $\mathrm{CH}_{4}$ appears to decline as the result of cell degradation. The conversion of $\mathrm{CO}_{2}$ and $\mathrm{CH}_{4}$ mainly depends on carbon dioxide electrolysis, the reverse water gas shift reaction, methane decomposition and the reverse Boudouard reaction. However, the detailed mechanism of biogas electrolysis still needs to be further investigated.

LCNT/YSZ/LSM-YSZ. Cell-2 was electrochemical switched at $850{ }^{\circ} \mathrm{C}$ in $20 \% \mathrm{CO}_{2} / 30 \%$ $\mathrm{CH}_{4} / 50 \% \mathrm{~N}_{2}$ atmosphere. Fig. 6 illustrates impedance data of LCNT electrode measured before and after potential reduction at $2.3 \mathrm{~V}$ for different time. The equivalent circuit of (LR1(R2Q1)(R3Q2) was used to fit all impedance spectra. L represents inductor of the system. The intercept of the real axis at high frequency reflects ohmic resistance R1, while the intercept of the real axis at low frequency stands for the total cell resistance. The difference between these two intercepts represents polarization resistance Rp. Two arcs are shown in the impedance spectra. The arc at high frequency (R2Q1) can be assigned to the charge transfer process for $\mathrm{CO}_{2}$ dissociation, while the arc at low frequency (R3Q2) can be assigned to mass transfer process including diffusion of reactant species to the active site (9). 


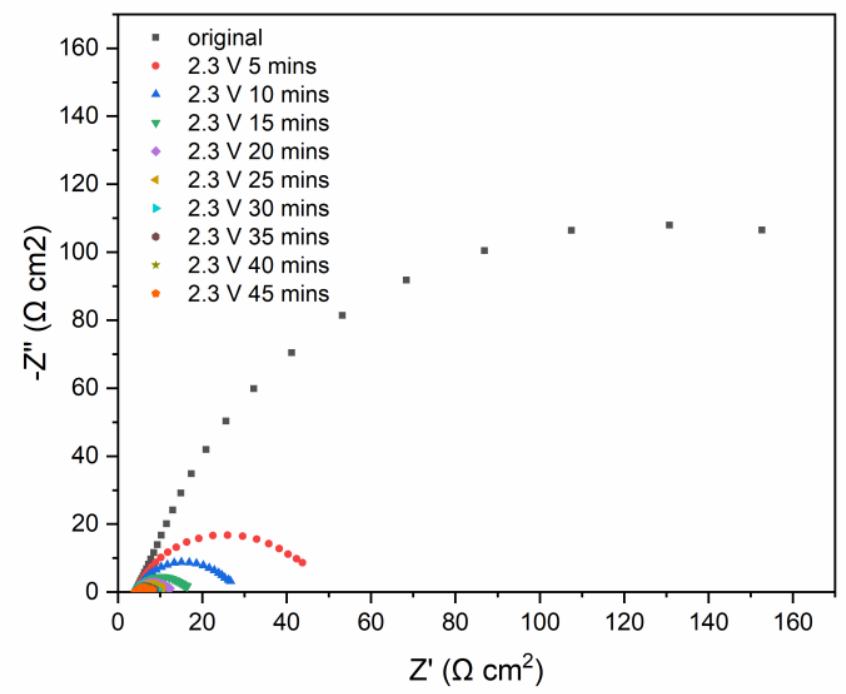

Figure 6. Impedance spectra under OCV condition before and after electrochemical switching for different time

TABLE II. EIS fitting values at OCV for cell-2 before and after electrochemical switching at $2.3 \mathrm{~V}$ for different time.

\begin{tabular}{cccc}
\hline & $\mathbf{R}_{\mathbf{1}}$ & $\mathbf{R}_{\mathbf{2}}$ & $\mathbf{R}_{\mathbf{3}}$ \\
\hline original & 3.694 & 24.600 & 177.800 \\
$2.3 \mathrm{~V}$ for 5 mins & 3.762 & 2.755 & 34.670 \\
$2.3 \mathrm{~V}$ for 10 mins & 3.748 & 1.853 & 18.440 \\
$2.3 \mathrm{~V}$ for 15 mins & 3.724 & 1.669 & 9.731 \\
$2.3 \mathrm{~V}$ for 20 mins & 3.699 & 1.368 & 6.491 \\
$2.3 \mathrm{~V}$ for 25 mins & 3.623 & 0.562 & 5.337 \\
$2.3 \mathrm{~V}$ for 30 mins & 3.599 & 0.398 & 4.160 \\
$2.3 \mathrm{~V}$ for 35 mins & 3.590 & 0.369 & 3.794 \\
$2.3 \mathrm{~V}$ for 40 mins & 3.546 & 0.368 & 3.298 \\
$2.3 \mathrm{~V}$ for 45 mins & 3.577 & 0.355 & 2.689 \\
\hline
\end{tabular}

With increasing time of loading, ohmic resistance only changes slightly, while polarization resistance decreases dramatically which mainly contributes by the low frequency arc. This suggests that mass transfer process becomes more efficient after potential reduction of LCNT electrode.

The electrochemical performance of cell-2 was evaluated at $850{ }^{\circ} \mathrm{C}$ after electrochemical switching. A current-voltage curve (Fig. 7 (a)) was collected from OCV to $2 \mathrm{~V}$. Fig. 7 (b) shows the impedance spectra for cell-2 recoded under different applied voltages. Rs remains constant along with the increasing external voltage indicating no structure changes occurred in the electrolyte/electrode interface region, whereas polarization resistance increases from OCV to $1.2 \mathrm{~V}$, while $\mathrm{R}_{\mathrm{p}}$ is in decreasing trend from $1.2 \mathrm{~V}$ to $1.8 \mathrm{~V}$. The results of impedance spectra is in good agreement with the slope calculated from I-V curve. 
(a)

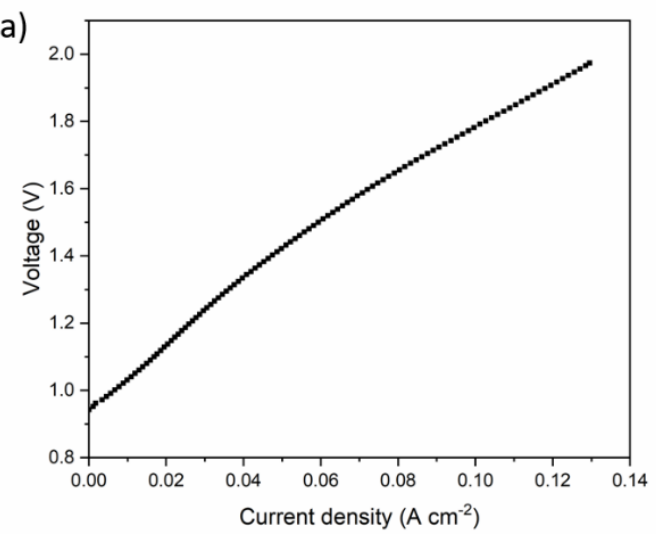

(b)

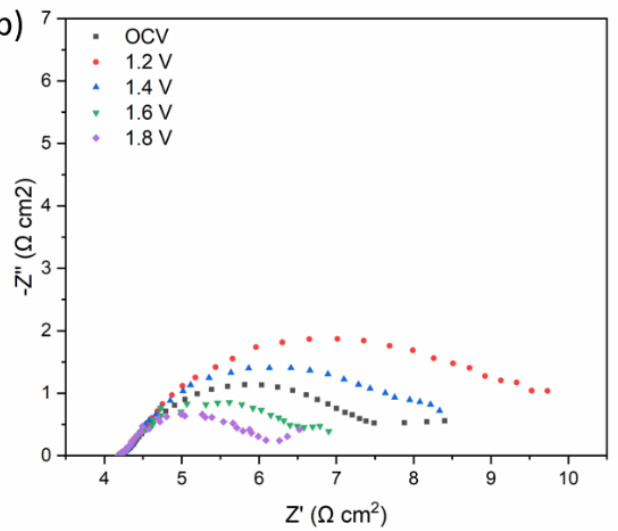

Figure 7. (a) Current-voltage curve from OCV to 2V; (b) Impedance spectra collected under different applied voltages

\section{Conclusions}

In conclusions, the state-of-the art electrodes were synthesised successfully and worked well for biogas electrolysis. The carbon deposition was not found in the final Ni/YSZ microstructure in cell-1 with the gas mixture of $20 \% \mathrm{CO}_{2} / 20 \% \mathrm{CH}_{4} / 60 \%$ Ar. The degradation of the cell performance might because of the material instability at high operation temperature. The conversion of $\mathrm{CO}_{2}$ is higher than the conversion of $\mathrm{CH}_{4}$ at $900{ }^{\circ} \mathrm{C}$ due to the influence of reverse water gas shift reaction. Alternative fuel electrode LCNT was successfully electrochemical switched in simulated biogas mixture. More details of electrochemical reaction happened in LCNT electrode need to be further investigate.

\section{Acknowledgments}

We acknowledge support from Low Emissions Resources Corp for funding.

\section{References}

1. Biogas \& Engines, https://www.clarke-energy.com/biogas/, (accessed 26 Mar, 2018).

2. D. Pakhare and J. Spivey, Chem. Soc. Rev., 43, 7813-7837 (2014).

3. J. R. H. Ross, Catal. Today, 100, 151-158 (2005).

4. N. A. K. Aramouni, J. G. Touma, B. Abu Tarboush, J. Zeaiter and M. N. Ahmad, Renewable \& Sustainable Energy Reviews, 82, 2570-2585 (2018).

5. C. Graves, S. D. Ebbesen, M. Mogensen and K. S. Lackner, Renewable \& Sustainable Energy Reviews, 15, 1-23 (2011).

6. D. Trommer, D. Hirsch and A. Steinfeld, Int. J. Hydrogen Energy, 29, 627-633 (2004).

7. $\quad$ S. P. S. Badwal, Solid State Ionics, 143, 39-46 (2001).

8. D. Simwonis, F. Tietz and D. Stover, Solid State Ionics, 132, 241-251 (2000).

9. S. Primdahl and M. Mogensen, J. Electrochem. Soc., 145, 2431-2438 (1998). 